\title{
LEGAL IMPACT OF STATE DEFENSE ON INDONESIAN CITIZEN IN INTERNATIONAL HUMANITARIAN LAW PRESPECTIVE
}

\author{
Gerald Aldytia Bunga; Elisabeth Nirmalasari Bota Tukan \\ Faculty of Law, University of Nusa Cendana \\ E-mail: gerald.bunga@yahoo.com; elisabeth.nirmala@gmail.com
}

\begin{abstract}
Implementation of state defense in Indonesia can be implemented in military and non-military. Civilians can also be involved in state defense including in those conducted militarily, therefore this study is aimed at examining how national law arrangements regulate the involvement of civilians in state defense which may be involved in military defense and how international humanitarian law regulates the involvement of civilians. This research uses normative legal research. The result of the research shows that involvement of civilians in military state defense can affect them losing the protection they should enjoy in armed conflict.
\end{abstract}

Keywords: State defense; International Humanitarian Law; Civilians.

\section{INTRODUCTION}

In the period of Indonesian independence, Bukit tinggi once served as a city of struggle and was appointed as the capital of the Indonesia after Yogyakarta fell into the hands of the Dutch or known as the Emergency Government of the Republic of Indonesia (PDRI) which formed on 19th of December 1948 in Bukit tingi, West Sumatra by Syafruddin Prawiranegara. Based on this event, the Indonesian government then set December 19th every time commemorated as a state defense day (Kemenhan, "Sejarah Bela Negara”, http://belanegara.kemhan.go.id/diklatbelanegara/ sejarah, acssesed on 31 of March 2017). The background of the struggle against the invaders is then developed in the present day as state defense which not only in terms of against the military but also in other matters that are not related to the military such as cultivate national insight through civic education or dedication through the profession of each citizen.

The 1945 Constitution of the Republic of Indonesia (hereinafter named to the 1945 Constitution) states that every citizen shall participate in the defense of the state (Article 27 Paragraph (3)). State defense efforts can be conducted in military form through taking up arms or through non-military ways. It is further stated in the 1945 Constitution that every citizen must participate in the efforts of defense and security

164 Yustisia Volume 8 Number 2 (May-August 2019)

Legal Impact Of State ...

(C)2019; This is an Open Acces Research distributed under the term of the Creative Commons Attribution Licencee (https://Creativecommons.org/licences/by/4.0), which permits unrestricted use, distribution, and reproduction in any medium, provided the original works is properly cited. 
of the state (Article 30 Paragraph (1)). It means that it is possible for every citizen to participate directly in armed conflict in Indonesia by taking up arms.

Lina Hastuti, in her research, says that the involvement of civilians in armed conflict as their obligation under 1945 Constitution in state defense can make them in an ambiguous position because they can be considered combatants but their position as civilians enjoys protection in international humanitarian law, in this research she mainly focus to discuss (Lina Hastuti,2012:18-19). The involvement of citizens who are civilians in a direct armed conflict will have different legal consequences for them when viewed in international humanitarian law. In general, international humanitarian law provides protection for civilians and civilian objects during armed conflict (Abdulrashid Lawan Haruna,et all, 2014: 15-16.), which means that during the armed conflict, parties of the conflict are forbidden to carry out attacks against civilians or civilian objects. This protection will be lost if civilians or civilian objects participate directly in armed conflict (Nils Melzer, 2009:14) Therefore, this study will be directed to see how the implementation of state defenses in Indonesia, especially in view of the possible use of civilian (citizen) involvement in the defense and security of the state, including in the case of taking up arms, in terms of international humanitarian law. Through this research it will be known how the legal consequences of involvement of civilians in an armed conflict that helps the citizens to understand their rights and obligations in carrying out state defense especially when armed conflict occurred. This paper aims to examine how the implementation of state defense in Indonesia can affect the civilians in prespective of international humanitarian law.

\section{RESEARCH METHODS}

The type of this research uses normative legal research, a legal research that is conducted based on law and regulation and library material, which is known as secondary material. Related with this type of research, the approach used in this paper are legal approach and historical approach. these approach are done by reviewing the acts and regulations that related to the problem that is being discussed in this research and also this research conduct a review on how the development of state defense in Indonesia from time to time.

\section{RESEARCH RESULT AND DISCUSSION}

\section{A. State Defense In National Law}

History has shown that for 350 years the Indonesian people lived in poverty, ignorance, and under the pressure of the invaders. The effort to win independence also sacrificed the life of the best sons of Indonesia. After independence, the 
threat is increasingly coloring the life of nation and state, both from within and from abroad.

Indonesia's geographic condition which consist of thousands of islands can be a challenge in itself. The difficulties experienced by the government and the security apparatus in securing the entire territory of the state, large populations, heterogeneous, and scattered in thousands of archipelagic areas make Indonesia more vulnerable to disintegrate and to intolerance. Indonesian natural resources and its potential also become an attraction for outsiders. These threats require the best defense and involvement of every member of society, both from the military and civilians.

The involvement of civilians in state defense is regulated in Article 27 Paragraph 3 of the 1945 Constitution of the Republic of Indonesia. This provision raises the state defese terms which are the subject of the discussion in this study. The involvement of civilians is further stipulated in Article 30 Paragraph (1) and (2) of the 1945 Constitution, which regulates the Defense and Security of the State. The two articles above show that the role of civilians in the defense and security of the state is not merely a duty but also a right, as reaffirmed in Article 68 of Law Number 39 of 1999 on Human Rights (Nurhidayatuloh, 2019: 40). Preamble of the 1945 Constitution states that the national goal is to protect the entire nation and the whole of Indonesia's blood sphere, to promote the common prosperity, to improve the life of the nation, and to participate in world order based on freedom, eternal peace, and social justice. To achieve these objectives, state defense is implemented through the universal defense and security system of the people (sistem pertahanan rakyat semesta), which places the TNI as the main force and civilians as a reserve and support component, in which every citizen has an obligation to participate in the state defense effort.

The nature of National Defense is all universal defense efforts which its implementation is based on awareness of citizens' rights and duties and on beliefs on their own strengths. The universal nature of the implementation includes all citizens, regions and other national resources, and is prepared in advance by the government and is held in total, integrated, directed and continuous manner to uphold the sovereignty of the state, territorial integrity and the safety of the whole nation from all threats. All national resources in the form of human, natural and artificial resources, values, technology, infrastructures and funds can be utilized to enhance the state's defense capabilities. The potential of national resources is all resources that can be utilized through the transformation process into the potential state defense force which can be used to increase the strength of the state defense. The transformation of national resources into the potential strength of the state defense is one of which is to build reserve 
components and supporting components, in order to strengthen and enlarge the main components of state defense (Timbur Siahaan, https://www.kemhan.go.id/ wp-content/uploads/2016/12/WIRA-EDISI-KHUSUS-fix-A4.pdf, acssesed on 30 of October 2017).

On 1954, Law Number 29 of 1954 on Principles of Civilians Resistance was passed. The law requires every citizen to participate in state defense (Article 2). The Law also provides that the state is manifested in the form of trained civilians and the armed force (Article 5). As the mplementation of the act, the Village Resistance Organization was established at the village level, which developed into the Village Security Organization, while the at schools was formed School Security Organization. This organization provides education of physical systems, techniques, tactics, and military strategy (Minto Rahayu, 2007:5)

Various threats experienced by the Indonesian changed in the new orde period and the reformation period. Threats encountered during this period are non-physical challenges and social upheaval. In 1973 MPR Decree Number IV/MPR/1973 on the Outline of State Policy $(G B H N)$ was issued, where there is an explanation of the Nusantara Insight and National Resilience, namely the Embodiment of the nusantara archipelago as a unit of defense and security which means that the threat to one island or one region is essentially a threat to all nation and state. It also provides that every citizen has the same rights and obligations in defending the state and nation. Thus the nusantara insight strengthens and facilitates the management of national resilience.

In accordance with the development of the period and content of the nusantara insight and national security mentioned above, the Law Number 20 of 1982 on the Principles of Defense of State Security was issued. This law clearly states that the people of Indonesia are the basis for the defense and security of the state (Article 2). The various provisions of this Law descriptively state the rights and obligations of citizens in state defense through the Education of Introduction of State Defense (PPBN), Trained Civilians (RATIH), the armed forces, TNI reserves, and the protection of the people (Article 18). The implementation is done in an urban environment, education environment, and employment environment, and the scout movement. The education given in the form of subjects of the curriculum start from kindergarten level up to university (Minto Rahayu, 2007:20).

The Trained civilians $(R A T I H)$ are specifically regulated in Law Number 56 of 1999 on Trained Civilians. RATIH consists of various elements, such as the Student Regiment (Menwa), People's Resistance (Wanra), Civil Defense (Hansip), Mitra Babinsa, and Youth Social Organization $(O K P)$ who have attended Military Basic Education, and others. Mandatory devotion of RATIH 
has four functions namely public order, public protection, people's security, and people's resistance. The first three functions are generally performed in peacetime or in the event of a natural disaster or civil emergency, where the elements of RATIH assist local governments in dealing with security and public order. While the function of the People's Resistance is carried out in war where RATIH is an element of support for regular TNI troops and is directly involved in the battlefield.

In the previous Law, there are also provisions which indicate that the involvement of a citizen in RATIH is a right and a duty. A member of RATIH who has worked is granted the right to take special leave to take part in the training without being fired from the agency where he/she works. Upon completion of the training, members of RATIH shall be entitled to the certification and if injured or died in training shall be entitled to a tribute mark or service mark or social security. Even eligible members of RATIH may be accepted or deployed to become members of the TNI (Chapter IV Article 22-26). The obligation to follow $R A T I H$ is seen from the threat of criminal sanctions that can be imposed on every citizen who deliberately avoids mandatory service, namely by imprisonment of not more than 9 months (Article 22). Leader of government departements, institutions, leaders of educational institutions that prevent the involvement of a person in consecrated service shall also be punished with imprisonment for a maximum of 1 year (Article 35).

Law number 20 of 1982 was replaced by Law Number 3 of 2002 on State Defense. Changes that occur in society and environment which influence the patterns and forms of threats are increasingly complex and multidimensional, in the form of military and non-military threats. The threats include global phenomenon of radicalism, hoax and terrorism, the presence of separatist movements in Indonesia, the existence of US military bases in Australia in 2011, violations of the sovereignty of Indonesia's territory in the South China Sea, and the involvement of some Indonesian citizens in ISIS network (Pratimun, 2016:21-26). Law Number 3 of 2002 mandates that the state defense system is organized by empowering all national resources, which are ready for use at any time (Article 2). The participation of citizens is stated in the Law as a reserve component and supporting components in state defense (Article 8).

The various legal provisions presented earlier indicate that it has been recognized that citizens have the potential to defend the state against all forms of threat, so that although the provisions of legislation continue to change, the provisions on citizen engagement are maintained, inclunding the engagement in armed conflict. 


\section{Definition Of State Defense In Various Regulations And Its Implementation}

Awareness to defend the state is one thing that is essential and must be owned by every citizen of Indonesia (WNI), as a manifestation of the rights and obligations in the effort to defend the state. Awareness to defend the state into the basic capital as well as the strength of the nation, in order to maintain the integrity, sovereignty and survival of the nation and state of Indonesia. The term defend the country was first present in Law Number 20 of 1982 on the Basic Provisions of Defense of the State of Indonesia, which states that state defending is the determination, attitude and actions of citizens are regular, comprehensive, integrated and continuous based on the love of homeland, national and state awareness of Indonesia As well as the belief in the power of Pancasila as the state ideology and the willingness to sacrifice to eliminate any threats from abroad or from within the country that endanger the independence and sovereignty of the state, unity and national unity, territorial integrity and national jurisdiction, as well as the values of Pancasila and the 1945 Constitution (Article 1).

The term reappears with a much simpler definition in Law Number 56 of 1999 on Trained Civilians, where state defenses are defined as attitudes and behaviors of citizens who are imbued with their love of the unitary state Republic of Indonesia based on Pancasila and the 1945 Constitution in the guarantee the survival of the nation and state.

In Law Number 3 of 2002 on National Defense does not define the state defense, but just as the two acts above emphasize the involvement of citizens in the defense of the state, where it is stated that every citizen has rights and obligations to participate in state defending efforts (Article 9 Point 1). It further stipulates that citizen participation in state defense efforts is conducted through civic education, compulsory basic military training, devotion as a voluntary or obligatory Indonesian National Army and dedication to the profession (Article 9 Point 2). Under these provisions, it is known that citizen participation in state defense is categorized as a military and non-military defense.

Basically there is no difference to the arrangements regarding the principle of state defend which is set in three of the Law above, both related to the definition of state defense, the nature of whether the memberships is the right and duty, as well as its purpose. It is just that there are slight differences in the regulation regarding the implementation of the participation of state defense as set forth in Article 9 of the State Defense Law and Article 18 of the Basic Provisions on Security Arrangements. This creates a lack 
of synchronization regarding the arrangement of participation in the states defense. Therefore, by referring to one of the principles in the legislation, the most recent regulations override the old rules (the principle of posterior lex derogat legi priori ), the implementation of citizen participation in the state defense refers to the provisions of Article 9 of the State Defense Law. Therefore, when referring to the provisions of the aforementioned article, government programs relating to state defense should not necessarily be directly carried out, but must wait for the legal umbrella in the form of act as mandated by Article 9 Paragraph (3) of the State Defense Act (Zaqiu Rahman, 2015:6).

In 2015, the Minister of Defense issued the Decree of Minister of Defense Number 19 of 2015 on the Implementation of State Defense in 2015-2019 on the basis of the 1945 Constitution Article 30 Paragraph 1 and Law Number 3 Year 2002 on State Defense Article 16 paragraph (3). In the "state defense" section of the Ministerial Decree, it is stated that the task of Ministry of Defense is to assist the Ministry/Institution/Local Government in the guidance of state defense and the promotion of non military abilities including the ability of early warning, the ability of state defense, the ability of diplomacy, the ability of science and technology, economic capability, social ability, moral ability, and capability to support the state defense.

Minister of Defense, Ryamizard Ryacudu, also explained that the state defense proposed by the Ministry of Defense is not by conscription. Minister of Defense asserted in the concept of state defense, the government wants to change the thought of its citizens to be proud as the nation of Indonesia. In accordance with Decree of Minister of Defense Number 19 of 2015, one form of state defense in education is the development of curriculum of state defense from kindergarten to college with the core component is to know the history of Indonesia, especially the history of the struggle to seize and defend the United State of the Republic of Indonesia. The state defense program is a program of the Ministry of Defense initiative. Thus defending the state is not conscription, but as a manifestation of state rights and obligations that need to be prepared (Riant Nugroho, https://www.kemhan.go.id/wpcontent/uploads/2016/12/WIRA-EDISI-KHUSUS-fix-A4.pdf, acssesed on 3 October 2017:64).

Non-military state defense is implemented through various DIKLAT (Short term course) since 22 October 2015 (Joko Riyanto, Wira July-August 2017, volume 67, number 51) organized by the Ministry of Defense given to civil society from various levels of education ( from early childhood to college), work environment, and age (Minister of Defence, https://www. 
kemhan.go.id/belanegara/jenis-diklat/, acssesed on 14 October 2017) . In Nusa Tenggara Timur alone, 27,868 cadres of state defenses have been scattered in 12 education centers, but no detailed data on implementation time, participant background, and type of training that have been conducted (minister of defence, https://www.kemhan.go.id/belanegara/statistik-kader/, acssesed on 14 October 2017).

With the provisions of Decree of Minister of Defense Number 19 of 2015 on the Implementation of State Defense in 2015-2019 and the explanation of the Minister of Defense does not mean that military state defense not being anticipated at all. With the stipulation of the provisions on state defense and the increasingly complex of threat to the nation, there is always a possibility of military efforts to defend the state. The limited number of the Army, Navy, Air Force and Police, which is not more than 1 million personnels, it is considered insufficient for the condition Indonesia which have seventeen thousand islands. Then the strategic method to do is to involve all components of the community as a reserve force to become the main support of the TNI. It can be understood that the state defense is not conscription but it is also make sense to conclude that the aim of this concept of state defense is to prepare the civilian as a strategic military reserve force if at any time needed (Gatut Priyowidodo, Mitra Indonesia, Ed 92 (129) Thn XI, January, 2016:7).

In Article 8 of Law Number 3 of 2002, Indonesian citizens are placed as supporting components and reserve components. Thus, if in the future Indonesia is involved in armed conflict then the above components can be utilized to assist the TNI. In the perspective of international humanitarian law, it can be a problem. In the International Humanitarian Law there is a principle of distinction which distinguishes the population into two groups namely combatants and civilians. Combatants are groups of people who are actively involved in combat and if arrested by opponents will become prisoner of war, while civilians are those who do not participate in combat, must be protected and should not be targeted for attacks. The placement of Indonesian citizens (civilians) as supporting components and reserve components in a situation of armed conflict will change the status of civilians to combatants, so they can be attacked and also can be prisoners of war.

\section{International Humanitarian Law Prespective on the Involvement of Civilians in State Defense}

In any armed conflict, whether it is international armed conflicts (ICRC, https://www.icrc.org/eng/assets/files/other/opinion-paper-armed-conflict. pdf. acssesed on 10 of Juli 2017) or non-international armed conflicts (ICRC, https://www.icrc.org/eng/assets/files/other/opinion-paper-armed-conflict. 
pdf, acssesed on 10 July 2017), it will always be related to the civilian population or object as well. Civilians are generally not directly involved in armed conflict. In many armed conflicts, civilians often become the victims even though they do not participate directly in the conflict. In the conflict in Iraq, as recorded by the Iraq Family Health Survey, civilian casualties recorded during the armed conflict took place there from March 2003 to June 2006 were 151,000 or 46,462 people per year (Physicians For Social Responsibility, et all, www.psr.org/assets/pdfs/body-count.pdf, acssesed on 10 of July 2017:22), while based on the Lancet Study the total number of victims related to armed conflict that occurred in Iraq in the period March 2003 to June 2006 was 655,000 or 201,538 deaths per year (Physicians For Social Responsibility, et all, www.psr.org/assets/pdfs/body-count.pdf, acssesed on 10 of July 2017:22). In the war on terror in Afghanistan, from 2007 to 2011, according to the Congressional Research Service (CSR) it is estimated that the number of civilians who were directly affected by the armed conflict that occurred there was 11,092 lives (Physicians For Social Responsibility, et all, www.psr.org/assets/pdfs/body-count.pdf, acssesed on 10 of July 2017:66). Meanwhile, the civilian population killed directly in the war on terror in Pakistan from 2004 to 2013 was 49,455 (Physicians For Social Responsibility, et all, www.psr.org/assets/pdfs/body-count.pdf, acssesed on 10 of July 2017:83) This shows that in the armed conflict the position of the civilian population is very vulnerable, therefore international humanitarian law provides protection to civilians during armed conflict, although civilian casualties remain unavoidable in any armed conflict.

International humanitarian law clearly provides protection to civilians and civilian objects during armed conflict, but in some circumstances civilians or civilian objects can be categorized as having been directly involved in armed conflict and therefore will lose the protection that should be enjoyed by them during the armed conflict. It can happen when civilians or civilian objects are involved in the defense of the state. To elaborate this issue, it will be examined below on how international humanitarian law sees civilians and objects in an armed conflict.

1) The Arrangement of Civilians in International Humanitarian Law

Civilian casualties in armed conflict are inevitable, but with the development of the legal system, especially international humanitarian law, the protection of civilians during armed conflict can be increased. The possibility of civilian casualties in the implementation of state defense is also possible because there is a possibility for the use of civilians and civilian objects to participate directly in armed conflict both 
to face threats from within and abroad, one of which may be a military threat that could trigger an armed conflict.

Therefore, in the section bellow, it will be discussed on how international humanitarian law provides protection to the civilian population in that situation. Firstly, it will be seen from the principles of international humanitarian law in providing protection for the civilian population and then proceeding to see how the current rules of international humanitarian law provide such protection.

\section{B. The Protection of Civilians Based on International Humanitarian Law Principles}

During the course of the armed conflict the parties of the conflict must comply international humanitarian law. The basic principle of international humanitarian law is the humanitarian principle that requires that even in a conflict situation humanitarian values are upheld and armed conflicts remain within humanitarian boundaries. This principle requires that all attempts or acts of violence by using such weapons or acts carried out to a certain degree which is not necessary for an armed conflict to be prohibited. Therefore any person who does not participate directly in an armed conflict such as a civilian is a group to be protected and should be treated humanely during the conflict (Robert Kolb and Richard Hyde, 2008:43-45)

Another basic principle in international humanitarian law is the principle of military necessity which by virtue of this principle the use of armed forces is justified in order to achieve legitimate military objectives, including to kill enemies or to destroy enemy facilities or buildings as long as it is necessary. It is just not permissible for either party in an armed conflict to commit an attack in order to retaliate or to attack other parties not participating directly in an armed conflict (Michael N Schmitt, Virginia Journal of International Law, Volume 50, Issue 4, 2010: 796-797 and Norhabib Bin Suod. S. Barodi, IIUM Law Journal Vol. 26 Issue.1, 2018:23-24).

These two basic principles strongly influence the establishment of the rules of international humanitarian law evenly. If only the principle of humanity dominates the rules produced then it will be difficult to apply such rules in armed conflict because basically this principle highly respects the life of each individual while the nature of the conflict is destructive or killing. On the contrary, if the principle of military necessity over-dominating, the resulting rule will lead to a total war that produces considerable damage and tends not to reduce the destructive effects of the armed conflict, so that it can be imagined that the concept of protection of civilians or civilian objects as well as those who no 
longer participating directly in armed conflict because illness, injury, or disability can be an unnecessary victim. Given the balance between these two principles in international humanitarian law, it is expected that the military objectives can be achieved without neglect the protection of civilians or civilian objects or those who no longer participate directly in the armed conflict.

These two basic principles are then further specified in several principles of international humanitarian law, first is the principle of limitation. Under this principle, the parties of armed conflict are limited to selecting the means of warfare and the weapons used in armed conflict (Article 35 Paragraph (1) of $1^{\text {st }}$ Additional Protocol of 1977 on The Protection of the Victims of International Armed Conflict), so that the parties of the conflict can fight fairly, avoiding the use of weapons that cause excessive injury that should have been avoided. The examples of the use of weapons prohibited in armed conflict are toxic weapons, chemical weapons, cluster bombs, or blinding laser weapons. The use of such weapons may result in unnecessary and non-discriminatory damage to both combatants and non-combatants. A real example of the use of these weapons at the present time can be found in armed conflict in Syria. In April 2017 there was an attack by Syrian government forces against Syrian rebels which the government forces used chemical weapons that caused the people around the place of the explosion to become short of breath, convulsions, and foam come out from their mouths. According to the Syrian Observatory for Human Rights, that attack killed 58 people including 11 children and about 300 others injured. Allegedly the weapons that were detonated in place contain sarin nerve substances that are highly toxic and 20 times more lethal than cyanide (http://www.bbc. com/indonesia/dunia-39499518. Acssesed on 28 of July 2017).

The second principle is the principle of proportionality. This principle requires that the parties of armed conflict must carry out the attacks on the basis of discrimination and not indiscriminate attacks. The point is that the parties in carrying out an attack must limit their attack only to legitimate military targets (Article 51 Paragraph (5) (b) of $1^{\text {st }}$ Additional Protocol of 1977 on The Protection of the Victims of International Armed Conflict). In addition, the parties to the conflict must also take the necessary measures to ensure that attacks are carried out in accordance with international humanitarian law (Article 57 Paragraph (2) (a) (iii) and Article 57 Paragraph (2) (b) of $1^{\text {st }}$ Additional Protocol of 1977 on The Protection of the Victims of International Armed Conflict and Ned Dobos, Ethics \& International Affairs, Vol.26, Issue 3, 2012:335), so that in achieving the military objectives, it does not cause a greater and unnecessary casualties (Robert P. Barnidge, http://mfa.gov.il/MFA_Graphics/MFA\%20Gallery/ Legal\%20Advocacy/Gaza.pdf, acsseses on 28 July 2017:277). This principle 
is basically aimed to ensure that in achieving its military objectives, the parties to the conflict still consider the number of civilian casualties that may arise as a result of the attack so that the unnecessary casualties can be minimalized and if civilian casualties fall further compared to the military advantage that will be obtained then based on this principle, the attack should not be implemented.

The third principle specified from the principle of humanity and the principle of military interest is the principle of distinction. Based on this principle, there is a distinction between who and what may be attacked, who and what should not be attacked, and who and what should be protected in an armed conflict. Those who may be attacked during the ongoing armed conflict are legitimate military targets which are combatants and military objects. The Geneva Conventions categorize those who may be viewed as combatants are Regular member of armed forces (Article 4 A Point 1 of Third Geneva Convention of 1949 on Treatment of Prisoner of War), Members of regular armed forces who profess allegiance to a government or an authority not recognized by the Detaining Power (Article 4 A Point 3 of Third Geneva Convention of 1949 on Treatment of Prisoner of War), militias or volunteer corps incorporated with the regular army (Article 4 A Point 1 dan 2 of Third Geneva Convention of 1949 on Treatment of Prisoner of War), an organized resistance movement or militias that is not incorporated with the regular army (Article 4 A Point 2 of Third Geneva Convention of 1949 on Treatment of Prisoner of War), and civilians who participated in the resistance movement (Article 4A Point 6 of Third Geneva Convention of 1949 on Treatment of Prisoner of War). These groups may be the target of attack in an armed conflict. Furthermore the principle of distinction emphasizes that parties to armed conflict must at any time distinguish between civilian populations and combatants and civilian objects with military objectives so that each attack is directed solely to military objectives and enlarges the protection of the population and civilian objects in armed conflict (Article 48 of $1^{\text {st }}$ Additional Protocol of 1977 on The Protection of the Victims of International Armed Conflict).

In relation to state defense exercised in Indonesia, which can be exercised through active involvement of civilians in armed conflict, based on the principle of distinction when civilians or civilian objects are not directly involved in armed conflict they enjoy the protection during the conflict and should not be a military target. This protection will disappear when civilians or civilian objects are directly involved in the armed conflict, suppose that civilians then actively take up arms or civilian objects are functioned to support armed groups by becoming weapons storage, then they will become legitimate military targets so that if it is attacked, then people who carry out attacks against them can not be prosecuted in violation of international humanitarian law. 
Thus it can be seen that in the principles of international humanitarian law it strongly emphasizes the protection of the civilians and civilian objects when an armed conflict occurs. It is mainly based on previous war events which indicate that the civilians or civilian objects are often become the victims in armed conflict and its condition always harming civilian groups. It is also a real threat to civilians or civilian objects when used in state defense to support state defense and security when armed conflict occurs by participating directly in the conflict. In international humanitarian law, there is a situation which civilians can involve in armed conflict where there was invansion from foreign state, it is called levee en masse. In this situation the civilians could use armed forces against the enemy, but it has to be noted that such measure has to be done spontaneusly. In this sense the civilians involved in levee en masse should be considered as combatant and therefore will be the legitimate military target. It is also a situation that could probably happened in state defense in Indonesia (Christoper Waters, Dalhousie Law Journal, Vol.37, Issue 2:773).

This is possible because the state defense by civil society in facing various threats both from within and outside the country, which one form of threat faced is a military threat (Article 7 of Law Number 3 of 2002 on State Defense), can be done through direct involvement in the conflict or it may also be known as mobilization. Mobilization can occur because there is a change of situation from a peaceful state to a critical condition in the concept of defense and security, forcing the state to mobilize a number of personnel to increase the reserve of equipment for defense and security purposes, as well as anything related to it (Pietro Verri, 1992:72). Under such conditions, civilian or civilian objects may be the target of an opponent's attack in the conflict. However, one thing to be remembered by each conflict participant is that at all times during an armed conflict, the parties shall not attack any civilian, civilian population or civilian object.

\section{The Protection of Civilians in International Humanitarian Law Regulations}

The Four Geneva Conventions of 1949 strongly emphasize the need of protection of civilians and civilian objects during the armed conflict. Even any combatant who has surrendered or can no longer fight should not be the target of attack by the conflicting parties. Regarding the protection of civilians this has been emphasized in the 1949 Geneva conventions as defined in Article 3 of the four conventions which set minimum standards in treating individuals in armed conflict.

In the case of armed conflict not of an international character occurring in the territory of one of the High Contracting Parties, each Party to the conflict shall be bound to apply, as a minimum, the following provisions: 
1) Persons taking no active part in the hostilities, including members of armed forces who have laid down their arms and those placed hors de combat by sickness, wounds, detention, or any other cause, shall in all circumstances be treated humanely, without any adverse distinction founded on race, colour, religion or faith, sex, birth or wealth, or any other similar criteria.

To this end, the following acts are and shall remain prohibited at any time and in any place whatsoever with respect to the above-mentioned persons:

a) violence to life and person, in particular murder of all kinds,mutilation, cruel treatment and torture;

b) taking of hostages;

c) outrages upon personal dignity, in particular, humiliating and degrading treatment;

d) the passing of sentences and the carrying out of executions without previous judgment pronounced by a regularly constituted court affording all the judicial guarantees which are recognized as indispensable by civilized peoples.

2) The wounded and sick shall be collected and cared for.

Based on this article it can be seen that in general the protection of civilians in armed conflict is strongly guaranteed by international humanitarian law, since minimum standards must be applied by all parties of armed conflict to treat each individual humanely and prohibit the use of punishment to anyone which consider inhuman by civilized people. This treatment is primarily directed at those who do not participate directly in armed conflict, in which the civilian population is generally such. The humane treatment is also required to be applied without discrimination on the ground of race, color, religion or belief, gender, birth or wealth, or other similar criteria. For that purpose the article also specifies in detail the unlawful actions against civilians and armed force member who can no longer fight, including: mutilation, cruel treatment, torture, hostage-taking, assault on the dignity of a person (embarrassing and the treatment that lowers a person's dignity), and the provision of punishment without going through legal proceedings. This is the standard that every party of the conflict must comply when an armed conflict has occurred. This is in line with what is contained in the principle of military necessity and the principle of humanity which requires that humane treatment should still be upheld in armed conflict but the military necessity are not sacrificed.

Article 51 Paragraph (1) of 1977 1st Additional Protocol on the Protection of Victims of International Armed Conflict also emphasizes that 
civilian populations and individual shall be protected from any threat of danger arising from military operations. Therefore, in Paragraph (2) it is emphasized that certain actions are forbidden to be conducted agains them, including:

a. Being targeted for attack;

b. Use of force whose main purpose is to spread terror to civilian populations or individuals;

c. Threats of use of force whose main purpose is to spread terror to civilian populations or individuals.

Based on this article it can be seen that it is expressly stated that civil society is not a legitimate military target because it can not be attacked, and use of force even in the threat stage are prohibited to be carried out against civil society. Thus it can be seen that the protection of civilians in armed conflict is enormous.

Specifically the rules of international humanitarian law governing the protection of civilians are the Fourth Geneva Convention of 1949 on the Protection of Civilians in War Time. This Convention divides the protection of civilians in armed conflict in four parts namely, first relating to general rules applicable to all civilians, irrespective of their nationality, residing in conflict areas. Rules relate to the protection of civilians in general such as the establishment of hospital zones and the evacuation of sick or injured civilians. Second, the rules that apply to people who are categorized as protected persons in a narrower sense which are foreign citizens caught in conflict areas (Article 4 of Fourth Geneva Convention of 1949 on the Protection of Civilians in War Time).

Third, it relates to the rules that provide protection to the enemy civilians namely those who are citizens of one of the parties involved in armed conflict within the territory of their counterparts (Robert Kolb dan Richard Hyde:2009:222). The definition of enemy civilians is then developed by the International Criminal Tribunal for Yugoslavia (ICTY), which includes neutral citizens who are not under diplomatic protection, stateless persons, and persons loyal to one of the conflicting parties but finds themselves in the territory of the opposing party though their nationality is the same (Robert Kolb dan Richard Hyde, 2009:223-224). the Fourth relates to the rules governing the relationship between the enemy civilians with some other protected civilian groups and the armed forces of the opposing party within the area being occupied (Robert Kolb dan Richard Hyde,2009:227). For example Article 35 of the Fourth Geneva Conventions provides that all 
persons with the intention of leaving the conflict area, either at a time when a new conflict erupts or during the conflict, shall be permitted to do so unless their departure from the territory is contrary to the national interest of the country in which they are located.

Humanitarian law also provides protection for civilians who find themselves among the active combat situations between two conflicting parties, this can be seen in Article 48 of 1st Additional Protocol of 1977 on the Protection of Victims of International Armed Conflict which provides that:

"In order to ensure respect for and protection of the civilian population and civilian objects, the Parties to the conflict shall at all times distinguish between the civilian population and combatants and between civilian objects and military objectives and accordingly shall direct their operations only against military objectives."

This article is a principle derived from the principle of distintion which requires each party of the conflict, at any time distinguish between civilian populations and combatants and between civilian objects and military targets. The parties are only allowed to carry out attacks on legitimate military targets. The attack must also consider the military advantage to be achieved with the possibility of civilian casualties resulting from such attacks as stressed in the principle of proportionality. This is done to respect and provide protection to civilians and civilian objects.

\section{The Lost of Protection of Civilians in the Implementation of State Defense}

As explained above, the civilians and civilian objects are basically included in a protected group during armed conflict, but the protection may be lost by direct participation in the armed conflict. This is what may occur when civilians are involved in the defense of the state. As can be seen in the previous discussion that in state defense, civilians can actively take up arms against foreign powers who want to occupy its territory, and thereby can cause them to loss of protection that they should enjoy under international humanitarian law. In this section, we will discuss how civilians can lose such protection within the framework of international humanitarian law.

As stipulated in Article 30 Paragraph (2) of the 1945 Constitution, the Indonesian State defense system is implemented based on the universal people's defense system (Pertahanan Rakyat Semesta) which consists of the Indonesian National Army (Tentara Nasional Indonesia/TNI) and the Indonesian National Police as the main force and the people as the supporting force. This is reaffirmed in Law Number 3 of 2002 on State Defense (State Defense Law) which states 
that the state defense system is a system of universal defense which involve all citizens, regions and other national resources, and prepared at an early stage by the government and held in total, integrated, directed, and continued to uphold the sovereignty of the state, territorial integrity, and the safety of the whole nation from all threats.

This state defense system is run by the TNI as a key component, supported by reserve components and supporting components that consits of citizens, natural resources, artificial resources and national infrastructure facilities that can be mobilized at times to strengthen main components in facing military and non-military threats. Article 7 Paragraph (2) of the State Defense Law states that TNI is the main component in facing military threats, but in facing non-military threats then, pursuant to Article 7 Paragraph (3) of the State Defense Law, the the state body other than one deals with defense matters become the main element to overcome these threats in accordance with the nature and threats encountered. Whether in facing military threats or non-military threats, based on Article 8 of the State Defense Law, the TNI may be supported by reserve components and supporting components including citizens, natural resources, artificial resources, and national facilities and infrastructures.

The military threats as meant in the State Defense Act are threats that use organized armed forces that are deemed to have capabilities to endanger state sovereignty, the territorial integrity of the state, and the safety of the entire nation. This military threat can take the form of :

1. Agression by using armed forces conducted by a state against the sovereignty of another the state, territorial integrity, and safety of the whole nation or in the form and manner, as state bellow:

a. Invasion. It is attack by the armed forces of other states against the territory of the United State of the Republic of Indonesia.

b. Bombardment. It is the use of other weapons carried out by the armed forces of other states against the territory of the United State of the Republic of Indonesia.

c. Blockade of ports or beaches or airspace of the United State of the Republic of Indonesia by the armed forces of other states.

d. Attacks by other countries armed forces against the army or navy or air force of TNI.

e. The armed forces of other states locates within the territory of the United State of the Republic of Indonesia based of an agreement whose conduct or existence is contrary to the provisions of the treaty.

f. The actions of a state that allows the use of its territory by other states as 
a preparatory area for aggression against the United State of the Republic of Indonesia.

g. The transfer of armed groups or mercenary by another state to commit acts of violence in the territory of the United State of the Republic of Indonesia or perform such acts above.

2. Violation of territory conducted by other countries, whether using ships or non-commercial aircraft.

3. Espionage committed by other states to seek and obtain military secrets.

4. Sabotage to destroy important military installations and vital national objects that endanger the safety of the nation.

5. Armed terror acts conducted by international terrorist networks or in collaboration with domestic terrorism or domestic terrorism that escalate into danger of sovereignty of the state, territorial integrity and safety of the whole nation.

6. Armed rebellion.

7. The civil war take place between armed groups and other armed groups.

In facing the military threats described above, TNI is the main component to deal with it, but in the State Defense Act there is still the possibility for the involvement of civilians (citizens) in supporting the TNI to face the military threat in question (Article 7 Paragraph (2) and Article 8 of Law Number 3 of 2002 on State Defense). Thus, it is possible for civilians to participate directly in facing of these military threats, including in the case of military threats that result in armed contact with foreign parties, for example when there is aggression by other states against the Indonesian. Under such conditions civilians who initially enjoy protection when an armed conflict occurs will lose the protection of being directly participated in the armed conflict. This is in accordance with the provisions of Article 51 Paragraph (3) of 1st Additional Protocol 1977 on the Protection of Victims of International Armed Conflict which states that "Civilians shall enjoy the protection afforded by this Section, unless and for such time as they take a direct part in hostilities."

The emphasis on the conditions under which the civilian population may lose its protection in the armed conflict in this article receives substantial support from other statees such as Mexico which stated that the provisions of this article can not be protected by other statees as they would be contrary to the intent and purpose of this protocol. While delegates from the United Kingdom stated that the provisions of this article is a very important agreement on exisisting customary international law (ICRC, https://ihl-databases.icrc.org/customary-ihl/ eng/docs/v1_rul_rule6, acssesed on 15 of October 2017). This shows that the direct participation of the civilians in armed conflict is important because it has 
enormous legal consequences for theirself in armed conflict, therefore it is very important for every Indonesian citizen who can engage in the defense of the state to understand the significance of these legal consequences.

In the case of civilians directly participate in an armed conflict, international humanitarian law divides some of the roles they can carry out so as to cause them to lose protection in the conflict. The Third Geneva Convention of 1949 on the Treatment of Prisoners of War, in Article 4, suggests that in some circumstances a civilian may be considered as a combatant in order to become a legitimate military target:

1) Militia or volunteer corps incorporated with reguler member of arm force.

2) Militia or organized resistance movement that is not incorporated with the regular arm force.

3) Civilians who participated in the liberation movement.

For the first and second category, there are some requirements that must be met by them to be considered as militia, volunteer corps, or resistance movement either incorporated or not corporated by regular army ie, first, there is a chain of command where someone will be responsible for the group. second, the group has an identifier emblem for their group and the emblem can be recognized from far distance. third, they carry arms openly in the fight. fourth, they perform their operations in accordance with the laws and customs of war. Especially for an organized militia or resistance movement, there is an additional requirement for them besides the four requirements mentioned beforehand that they must have a link with either party of the armed conflict. One way to prove this link is for example by looking at the supply of weapons or llogistics from the regular army to the militia or organized resistance movement. As for the civilians who participated in the liberation movement then the act of resistance is done spontaneously and instantly when the invasion by foreign parties to his state happen.

Thus it can be seen that in the implementation of state defense in Indonesia, civilians as a reserve component or supporting components, under international humanitarian law, can be used as a militia, volunteer corps or organized resistance movement either incorporated with TNI or not or in context when there is aggression, civilians can make a spontaneous and instantaneous resistance to the troops who carry out the aggression. By doing so civilians will no longer be considered civilian but combatant and therefore will become legitimate military target and they will loss the protection in armed conflict. 


\section{CONCLUSSION}

Law Number 3 of 2002 has established citizens as reserve component and supporting components in the defense of the state in facing both military and non military threats. State defense is basically not a conscription, but with the stipulation of provisions on state defense and threats against the increasingly complex Indonesian nation, it is always open the possibility of military efforts to defend the country. If, in the militarily defense of the state, the civilians is directly involved, then with its involvement both organized and spontaneously, the civilians will no longer be considered civilian but combatant and will therefore become legitimate military target and will loss the protection in armed conflict.

\section{BIBLIOGRAPHY:}

\section{Books:}

Kolb Robert and Hyde Richard. (2008). An Introduction to International Law of Armed Conflict. Oregon: Hart Publishing.

Melzer Nils. (2009). Interpretive Guidence on the Notion of Direct Participationin Hostilities Under International Humanitarian Law. ICRC.

MPR RI. (2007). Society Guidence of The 1945 Constitution of The Republic of Indonesia (Panduan Pemasyarakatan Undang-Undang Dasar Negara Indonesia Tahun 1945). Sekretariat Jenderal MPR RI.

Kadir, Muhammad Abdul. (2004). Law and Legal Research (Hukum dan Penelitian Hukum), Bandung: Citra Aditya Bakti.

Pietro, Verri. (1992). Dictionary of the International Law of Armed Conflict. Geneva: International Committee of the Red Cross.

Pratimun. (2016). Program Bela Negara Guna Menyikapi Kebhinekaan Bangsa Indonesia. Jakarta: Seskoad.

Priyowidodo, Gatut. (2016). Bela Negara, Bela Bangsa, Bela Agama, MITRA INDONESIA, Edisi 92 (129) Thn XI Januari 2016.

Rahayu, Minto. (2007). Pendidikan Kewarganegaraan Perjuangan Menghidupi Jati Diri Bangsa. Grasindo.

\section{Journals:}

Barodi Norhabib Bin Suod. S. (2018). Rethinking the issue of non-compensability of Civilian losses caused by security forces During non-international armed 
conflicts: the Case of the marawi crisis in the philippines. IIUM Law Journal Volume 26 Issue 1.

Dobos Ned. (2012). International Rescue and Mediated Consequences. Ethics \& International Affairs, Volume 26, Issue 3.

Haruna Abdulrashid Lawan,et. al. (2014). Principle of Distinction in Armed Conflict: An Analysis of the Legitimacy of 'Combatants and Military Objectives' As a Military Target. International Journal of Humanities and Social Science Invention, Volume 3 Issue 3.

Nurhidayatuloh, et. al. (2019). ASEAN and European Human Rights Mechanisms, What Should be Improved?. Padjadjaran Journal of Law, Volume 6, Number 1.

Rahman Zaqiu. (2015). Program Bela Negara sebagai perwujudan Hak dan Kewajiban Negara dalam Penyelenggaraan Pertahanan Negara, Jurnal Rechtsvinding.

Riyanto, Joko. (2017). Kewaspadaan Nasional, Bela Negara, dan Integrasi Nasional. Wira Edisi Juli-Agustus, Volume 67, Number 51.

Schmitt Michael N. (2010). Military Necessity and Humanity in International Humanitarian Law: Perserving Delicate Balance. Virginia Journal of International Law, Volume 50, Issue 4.

Waters Christoper. (2014). New Hacktivists and the Old Concept of Levee and Masse. Dalhousie Law Journal, Volume 37, Issue 2.

\section{Legal Documents:}

1945 Constitution of The Republic of Indonesia;

Law Number 24 of 1954 on Principles of Civilians Resistance (State Gazette Number 1 of 1952);

Law Number 20 of 1982 on Principles of State Security and Defense (State Gazette Number 51 of 1982);

Law Number 39 of 1999 on Human Rights (State Gazette Number 165 of 1999);

Law Number 56 of 1999 on Trained Civilians (State Gazette Number 126 of 1999);

Law Number 3 of 2002 on State Defense (State Gazette Number 3 of 2002);

Third Geneva Convention of 1949 on the Treatment of Prisoner of War

Fourth Geneva Convention of 1949 on the Protection of Civilians in Time of War

$1^{\text {st }}$ Additional Protocol of 1977 on the Protection of Victims of International Armed Conflict

\section{Websites:}

Robert P. 2010. "the Principle of Proportionality Under International Humanitarian Law and Operation Cast Lead"...http://mfa.gov.il/MFA_Graphics/MFA\%20 
Gallery/Legal\%20Advocacy/Gaza.pdf; accessed on 28 July 2019;

ICRC. 2008, "How Is The Term "Armed Conflict" Defined In International Humanitarian Law:. https://www.icrc.org/eng/assets/files/other/opinion-paperarmed-conflict.pdf, accessed on 10 July 2019;

ICRC, "Rule 6. Civilians' Loss of Protection from Attack", https://ihl-databases. icrc.org/customary-ihl/eng/docs/v1_rul_rule6, accessed on 10 July 2019;

Physicians For Social Responsibility, et all. 2015. "Body Count: Causalties Figures After 10 Years of the War on Terror - Iraq, Afghanistan, Pakistan-“. www.psr. org/assets/pdfs/body-count.pdf, accessed on 10 July 2019;

Siahaan Timbur, Bela Negara dan Kebijakan Pertahanan, Wira edisi khusus Bela Negara 2016, https://www.kemhan.go.id/wp-content/uploads/2016/12/WIRAEDISI-KHUSUS-fix-A4.pdf, accessed on 10 July 2019

Pusat Komunikasi Publik Kementerian Pertahanan, Narasi Tunggal Peringatan Hari Bela Negara Nasional 2016, https://maritim.go.id, accessed on 10 July 2019 